Review

\title{
Research Advances in Cadmium Uptake, Transport and Resistance in Rice (Oryza sativa L.)
}

\author{
Jialiang Zhang ${ }^{1,2,+}$, Yanchun Zhu ${ }^{1,2,+}$, Lijuan $\mathrm{Yu}^{3}{ }^{\mathbb{D}}$, Meng Yang ${ }^{1,4}$, Xiao Zou ${ }^{1,2}$, Changxi Yin ${ }^{1,2, * \mathbb{D}}$ \\ and Yongjun Lin 1,4
}

check for

updates

Citation: Zhang, J.; Zhu, Y.; Yu, L.; Yang, M.; Zou, X.; Yin, C.; Lin, Y. Research Advances in Cadmium Uptake, Transport and Resistance in Rice (Oryza sativa L.). Cells 2022, 11, 569. https://doi.org/10.3390/ cells11030569

Academic Editor: M. Margarida Oliveira

Received: 27 December 2021

Accepted: 1 February 2022

Published: 6 February 2022

Publisher's Note: MDPI stays neutral with regard to jurisdictional claims in published maps and institutional affiliations.

Copyright: (C) 2022 by the authors. Licensee MDPI, Basel, Switzerland. This article is an open access article distributed under the terms and conditions of the Creative Commons Attribution (CC BY) license (https:// creativecommons.org/licenses/by/ $4.0 /)$.
1 National Key Laboratory of Crop Genetic Improvement, Huazhong Agricultural University, Wuhan 430070, China; zhangjialiang@webmail.hzau.edu.cn (J.Z.); zhuyanchun@webmail.hzau.edu.cn (Y.Z.); liulangx@webmail.hzau.edu.cn (M.Y.); zouxiao@webmail.hzau.edu.cn (X.Z.); yongjunlin@mail.hzau.edu.cn (Y.L.)

2 MOA Key Laboratory of Crop Ecophysiology and Farming System in the Middle Reaches of the Yangtze River, College of Plant Science and Technology, Huazhong Agricultural University, Wuhan 430070, China

3 Agro-Products Processing Research Institute, Yunnan Academy of Agricultural Sciences, Kunming 650221, China; yulijuan1000@163.com

4 College of Life Science and Technology, Huazhong Agricultural University, Wuhan 430070, China

* Correspondence: yinchangxi@mail.hzau.edu.cn; Tel.: +86-278-728-2130

+ These authors contributed equally to the work.
Abstract: Rice (Oryza sativa L.) is one of the most important food crops, feeding half of the world's population. However, rice production is affected by cadmium (Cd) toxicity. Due to an increase in $\mathrm{Cd}$-contaminated soil and rice grains, and the serious harm to human health from $\mathrm{Cd}$, research on $\mathrm{Cd}$ uptake, transport and resistance in rice has been widely conducted, and many important advances have been made. Rice plants absorb Cd mainly from soil through roots, which is mediated by $\mathrm{Cd}$ absorption-related transporters, including OsNramp5, OsNramp1, OsCd1, OsZIP3, OsHIR1, OsIRT1 and OsIRT2. Cd uptake is affected by soil's environmental factors, such as the concentrations of $\mathrm{Cd}$ and some other ions in soil, soil properties, and other factors can affect the bioavailability of Cd in soil. Then, Cd is transported within rice plants mediated by OsZIP6, OsZIP7, OsLCD, OsHMA2, CAL1, OsCCX2, OsLCT1 and OsMTP1, from roots to shoots and from shoots to grains. To resist Cd toxicity, rice has evolved many resistance strategies, including the deposition of $\mathrm{Cd}$ in cell walls, vacuolar $\mathrm{Cd}$ sequestration, $\mathrm{Cd}$ chelation, antioxidation and $\mathrm{Cd}$ efflux. In addition, some unresolved scientific questions surrounding $\mathrm{Cd}$ uptake, transport and resistance in rice are proposed for further study.

Keywords: cadmium; uptake; transport; Cd deposition; vacuolar sequestration; chelation; antioxidation; efflux

\section{Introduction}

In recent years, the $\mathrm{Cd}$ content of farmland soils has continuously increased due to increasing discharges of industrial wastewater, waste gas and other residues, excessive use of metal-containing pesticides and fertilizers. The total concentration of $\mathrm{Cd}$ in agricultural soils is higher than that in non-agricultural soils [1]. Compared to survey results from 1990, the $\mathrm{Cd}$ content of Chinese soil has generally increased and continues to increase. About 20,000 hectares of farmland in China was contaminated with Cd [2]. The concentration of $\mathrm{Cd}$ in rice grains grown on farmland with heavy $\mathrm{Cd}$ contamination has exceeded the global safety standard level $(\leq 0.4 \mathrm{mg} / \mathrm{kg})$, rendering the grains inedible [3].

Rice is the main source of $\mathrm{Cd}$ in Chinese diet, and 55\% of Cd intake by the Chinese population is from rice [4]. Cd enters the rice plant mainly through the roots and is transported to the shoots through sieve tubes and vessels and then transported to the grains. $\mathrm{Cd}$ enters the human body through the food chain, causing toxic effects on numerous systems, including the bones, heart and cerebral vessels and the nervous system. Moreover, $\mathrm{Cd}$ is 
not readily excreted from the human body and, therefore, causes long-term harm to human health. In addition, $\mathrm{Cd}$ pollution can affect rice growth and development and ultimately reduce rice yield [2].

Taken together, it is important to investigate the mechanisms of Cd uptake, transport and resistance in rice. In recent decades, scientists have made many important advances in understanding $\mathrm{Cd}$ uptake, transport and resistance in rice. Here, we introduce and discuss the research progress in this field. We also explore unresolved scientific questions regarding $\mathrm{Cd}$ uptake, transport and resistance in rice that demand further study in the future. The research progress in this field can be used to reduce the Cd-caused yield loss by enhancing rice resistance to $\mathrm{Cd}$ toxicity, produce safe rice grains by reducing $\mathrm{Cd}$ accumulation in rice grains and repair the $\mathrm{Cd}$-contaminated paddy fields by cultivating and planting rice varieties with strong $\mathrm{Cd}$ enrichment.

\section{Cd Uptake}

Rice plants primarily absorb heavy metal ions through their roots. Roots are the first organ to contact $\mathrm{Cd}$ in the soil and also the first barrier used by rice to resist $\mathrm{Cd}$ toxicity. $\mathrm{Cd}$ concentration in rice roots is significantly higher than that in aerial organs [5]. Cd is actively absorbed by rice root mainly through the symplasmic pathway by which $\mathrm{Cd}$ is transported into the rice root cell by carrier protein by consuming energy; then, $\mathrm{Cd}$ is transported into the root vascular cylinder via plasmodesmata [6-8]. In addition, $\mathrm{Cd}$ is able to be passively absorbed by rice root through extracellular compartment, such as the intercellular space. If $\mathrm{Cd}$ concentration outside of the root cell is higher than that inside of the root cell, $\mathrm{Cd}$ can diffuse into the root cell without consuming energy [6-8].

\subsection{Cd Uptake Mediated by Transporters}

OsNramp5, a member of the rice natural resistance-associated macrophage protein (Nramp) family, is a membrane transporter involved in Cd and manganese (Mn) uptake by rice roots. This transporter is polarly localized on the distal sides of both exodermis and endodermis cells and is the main pathway through which rice roots absorb $\mathrm{Cd}$ and $\mathrm{Mn}$ (Figure 1, Table 1) [9]. Previous studies have demonstrated that the knockout or knockdown of OsNramp5 significantly reduces Cd uptake capacity of the root system, thereby reducing the $\mathrm{Cd}$ contents in rice shoots and grains $[9,10]$. A knockout of OsNramp5 significantly reduces the content of $\mathrm{Cd}$ in rice grains without affecting rice yield [5]. However, in $\mathrm{Mn}$ deficient soils, OsNramp5-knockout rice mutants have reduced yield due to Mn deficiency, which is caused by a reduction in Mn uptake capacity, and translocation of Cd from roots to shoots was increased [5,9]. Interestingly, overexpression of OsNramp5 significantly increases the content of $\mathrm{Cd}$ in the roots, but markedly reduces it in aerial organs, such as straw and grains, by inhibiting the loading of Cd into the xylem [11]. This suggests that overexpression of OsNramp5 may be an effective strategy for reducing $\mathrm{Cd}$ accumulation in rice grains.

OsNramp1, a $\mathrm{Cd}$ transporter that can be up-regulated in response to $\mathrm{Cd}$, participates in the absorption and transport of Cd in rice (Figure 1, Table 1) [12-14]. Overexpression of OsNramp1 increases the $\mathrm{Cd}$ concentration in rice leaves, whereas its knockout reduces $\mathrm{Cd}$ accumulation in rice shoots and grains. In addition, compared to wild-type yeast, yeast expressing rice OsNramp1 suffers more serious toxicity under Cd stress [13].

As the physical and chemical properties of $\mathrm{Cd}$ ions are similar to zinc $(\mathrm{Zn})$ and iron (Fe) ions, $\mathrm{Cd}$ ions can be transported into rice cells through $\mathrm{Zn}$ and Fe transporters. The $\mathrm{Zn}$ and Fe transporters OsIRT1 and OsIRT2, which transport Zn and Fe across the membrane, have high affinities for $\mathrm{Cd}$ (Table 1). These two transporters are induced by Fe deficiency and can improve the resistance of rice plants to Fe deficiency, while also enhancing the absorption and transport of $\mathrm{Cd}$ and increasing the Cd content in rice (Figure 1) [15-17]. It has been reported that increased expression of OsIRT1 leads to increased Cd accumulation in rice [18]. In addition, $\mathrm{NaCl}$ can up-regulate the expression of IRT2 and promote the absorption of $\mathrm{Cd}$ by plants $[19,20]$. 


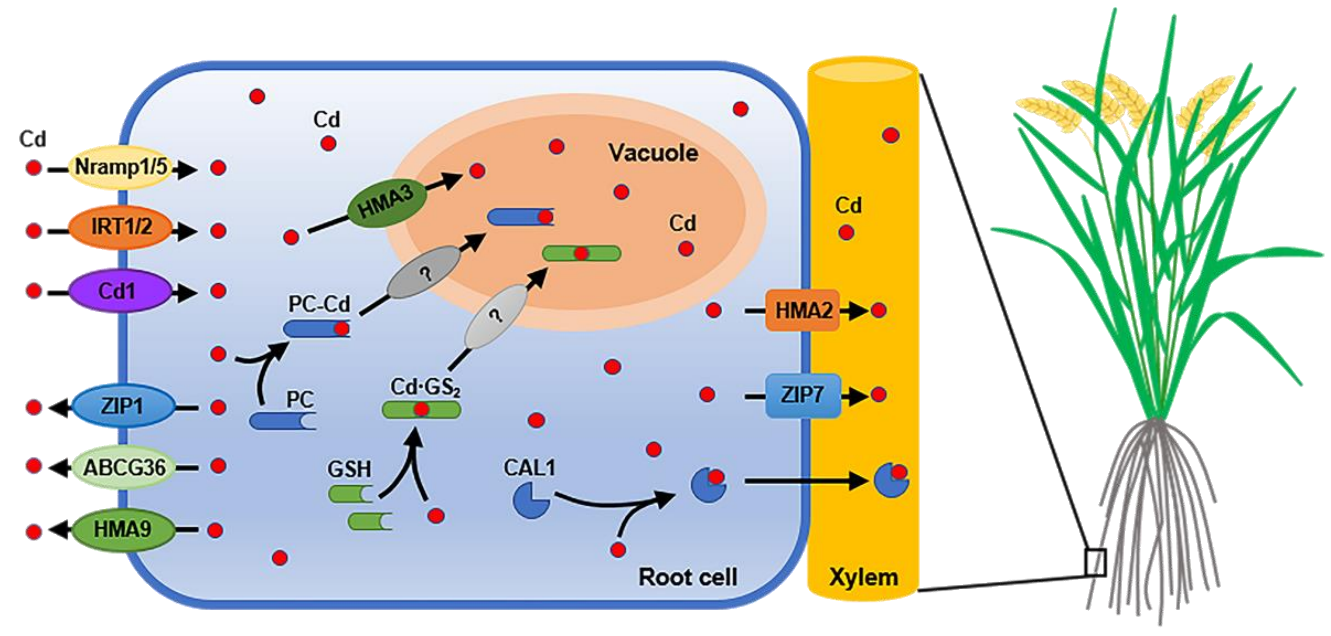

Figure 1. Schematic diagram of Cd uptake, efflux, vacuolar sequestration and loading into xylem in rice root. Cd is absorbed by root cells from soil, which is mediated by OsNramp1, OsNramp5, OsIRT1, OsIRT2 and OsCd1. After entering root cells, $\mathrm{Cd}$ is able to be transported into vacuole by OsHMA3 for sequestration. $\mathrm{Cd}$ is also to be chelated with PC or GSH and then transported into vacuole in the form of chelates, but the transporters that can transport PC-Cd and Cd.GS 2 into vacuole have not been identified. OsZIP1, OsHMA9 and OsABCG36 mediate the efflux of Cd, while OsHMA2, OsZIP7 and CAL1 mediate the loading process of $\mathrm{Cd}$ into xylem in rice root.

Table 1. Cd uptake, transport and resistance-related genes in rice.

\begin{tabular}{|c|c|c|c|c|}
\hline Gene & GenBank & Protein Product & Function & References \\
\hline OsNramp5 & LOC_Os07g15370 & Natural resistance-associated macrophage protein & Cd uptake & {$[5,9-11]$} \\
\hline OsNramp1 & LOC_Os07g15460 & Natural resistance-associated macrophage protein & Cd uptake & [12-14] \\
\hline OsIRT1 & LOC_Os03g46470 & Iron-regulated transporter & Cd uptake & [15-18] \\
\hline OsIRT2 & LOC_Os03g46454 & Iron-regulated transporter & Cd uptake & {$[16,17,19,20]$} \\
\hline OsCd1 & LOC_Os03g02380 & Major facilitator superfamily & Cd uptake & [21] \\
\hline OsZIP3 & LOC_Os04g52310 & Zinc- and iron-regulated transporter & Cd uptake & [22] \\
\hline OsHIR1 & LOC_Os08g30790 & Hypersensitive induced reaction protein & Cd uptake & [23] \\
\hline OsZIP6 & LOC_Os05g07210 & Zinc- and iron-regulated transporter & Cd transport & [24] \\
\hline OsLCD & LOC_Os01g72670 & Low cadmium & Cd transport & [25] \\
\hline OsHMA2 & LOC_Os06g48720 & P-type heavy metal ATPase & Cd transport & [26-28] \\
\hline CAL1 & LOC_Os02g41904 & Defensin-like protein & Cd chelationCd transport & [29] \\
\hline OsMTP1 & LOC_Os05g03780 & Metal tolerance protein & Cd transport & [30] \\
\hline OsZIP7 & LOC_Os05g10940 & Zinc- and iron-regulated transporter & Cd transport & [31] \\
\hline OsCCX2 2 & LOC_Os03g45370 & Cation/calcium (Ca) exchanger & Cd transport & [32] \\
\hline OsLCT1 & LOC_Os06g38120 & Low affinity cation transporter & Cd transport & [33] \\
\hline OsCDT1 & LOC_Os03g45370 & Cation/calcium $(\mathrm{Ca})$ exchanger & Cd deposition & [34] \\
\hline OsHMA3 & LOC_Os07g12900 & P-type heavy metal ATPase & Cd sequestration & [35-37] \\
\hline OsABCG43 & LOC_Os07g33780 & ATP binding cassette (ABC)-type transporter & Cd sequestration & {$[38]$} \\
\hline OsHsfA4a & LOC_Os01g54550 & Heat shock transcription factor gene & Cd chelation & [39] \\
\hline OsRCS1 & LOC_Os12g42980 & Cysteine synthase & Cd chelation & [40] \\
\hline OsPCS5 & LOC_Os06g01260 & Phytochelatin synthase & Cd chelation & [41] \\
\hline OsPCS15 & LOC_Os05g34290 & Phytochelatin synthase & Cd chelation & [41] \\
\hline $\operatorname{rg} M T$ & LOC_Os11g47809 & Type 1 metallothionein & Cd chelation & [42] \\
\hline OsCLT1 & LOC_Os01g72570 & CRT-like transporter & Antioxidation & [43] \\
\hline OsMSRMK3 & LOC_Os06g48590 & Mitogen-activated protein kinase & Antioxidation & [44] \\
\hline OsWJUMK1 & LOC_Os01g47530 & Mitogen-activated protein kinase & Antioxidation & [44] \\
\hline OsAUX1 & LOC_Os01g63770 & Auxin transport protein & Antioxidation & [45] \\
\hline OsHMA9 & LOC_Os06g45500 & P-type heavy metal ATPase & Cd efflux & [46] \\
\hline OsZIP1 & LOC_Os01g74110 & Zinc- and iron-regulated transporter & Cd efflux & [47] \\
\hline OsABCG36 & LOC_Os01g42380 & PDR-type ABC transporter 9 & Cd efflux & [48] \\
\hline
\end{tabular}

In addition, OsCd1, OsZIP3 and OsHIR1 are also involved in Cd uptake [21-23]. It has been reported that OsCd1 was localized on the plasma membrane of roots, and $\mathrm{Cd}$ accumulation in rice plants of OsCd1 knockout lines was significantly lower than that in wild-type rice (Figure 1, Table 1) [21]. Ectopic expression of OsZIP3 in yeast cells results in reduced absorption of $\mathrm{Cd}$, leading to reduced Cd toxicity (Table 1) [22]. Ectopic expression 
of OsHIR1 in transgenic Arabidopsis reduces Cd accumulation in roots and buds, thereby enhancing Cd tolerance (Table 1) [23].

\subsection{Cd Uptake Affected by Environmental Factors}

Uptake of $\mathrm{Cd}$ by rice roots is influenced by environmental factors, such as the concentrations of $\mathrm{Cd}$ and some other ions in soil [49-51], soil properties, including soil $\mathrm{pH}$ [52], nitrogen source [53], soil organic matter [54], rhizosphere microorganisms [55], and other factors can affect the bioavailability of $\mathrm{Cd}$ in soil.

Generally, the uptake of $\mathrm{Cd}$ by rice is positively correlated with $\mathrm{Cd}$ concentration in soil [49]. It has been reported that some metallic elements, including $\mathrm{Na}$, have enhancing effects on Cd uptake by plants [56,57]. By contrast, other metallic elements, such as calcium $(\mathrm{Ca})$, magnesium $(\mathrm{Mg})$, manganese $(\mathrm{Mn})$, potassium $(\mathrm{K})$ and silicon $(\mathrm{Si})$ have inhibitory effects on Cd uptake $[50,51,58]$. In soil solution, excessive release of Mn through dissolution of Mn oxides inhibits the absorption of $\mathrm{Cd}$ by rice roots. Mn oxide with strong capacities of oxidation and adsorption can affect the bioavailability of $\mathrm{Cd}$ and the amount of $\mathrm{Cd}$ adsorbed onto other metal oxides. Moreover, $\mathrm{Cd}$ and $\mathrm{Mn}$ enter rice root cells through ion channels and carrier proteins, and $\mathrm{Mn}$ inhibits $\mathrm{Cd}$ uptake through competition with ion channels and carrier proteins [50].

Among soil properties, $\mathrm{pH}$ has a significant effect on the concentration of available $\mathrm{Cd}$ in the soil [52]. When the soil is highly acidic, the amount of available $\mathrm{Cd}$ in soil increases, promoting the absorption of $\mathrm{Cd}$ by rice roots. When the soil is highly alkaline, free $\mathrm{Cd}$ in the soil will become conjugated $\mathrm{Cd}$, reducing the bioavailability of $\mathrm{Cd}$ and thus the uptake of $\mathrm{Cd}$ by rice [52]. It has been reported that excessive application of nitrogen fertilizer can lead to soil acidification and promote $\mathrm{Cd}$ uptake [53]. In recent years, soil acidification in China and other countries has been most often caused by excessive application of nitrogen fertilizer [53]. Soil acidification can reduce the adsorption of $\mathrm{Cd}$ by soil particles [59], increase the concentration of available $\mathrm{Cd}$ in soil and, therefore, increase the absorption and accumulation of $\mathrm{Cd}$ by rice $[60,61]$. By contrast, the application of alkaline substances, such as lime and grass ash, can improve the ability of soil to neutralize acids, enhance the $\mathrm{Cd}$ adsorption capacity of soil and reduce the bioavailability of $\mathrm{Cd}$, thus reducing the absorption of $\mathrm{Cd}$ by rice roots and the accumulation of $\mathrm{Cd}$ in rice grains [59,62]. Additionally, salinity can increase the absorption of $\mathrm{Cd}$ by plant roots and reduce Cd resistance in Raphanus sativus L. [19,63], while high concentration of Cd has no effect on semi-halophyte Mesembryanthemum crystallinum L. [64]. Phenolic and carboxylic acid groups of soil organic matter can be complexed with $\mathrm{Cd}$ to form highly conjugated macromolecules, reducing the availability of Cd [54], while rhizosphere microorganisms can promote $\mathrm{Cd}$ uptake by rice roots through various mechanisms, including increasing the bioavailability of $\mathrm{Cd}$ in soils [55].

\section{Cd Transport}

\subsection{Cd Transport from Roots to Shoots}

$\mathrm{Cd}$ transport from roots to shoots is mediated mainly through the xylem, while only a small amount is transported to shoots through the phloem. Increasing evidence suggests that OsZIP6, OsZIP7, OsLCD, OsHMA2, CAL1 and OsMTP1 play important roles in mediating Cd transport in rice (Table 1) [24-31].

It has been reported that the ZIP family members, including OsZIP6 and OsZIP7, are involved in the transport of Cd in rice. OsZIP6 was predicted to be localized on the plasma membrane in root and shoot tissues and was involved in $\mathrm{Cd}$ transport from roots to shoots, but the specific mechanism by which OsZIP6 transports $\mathrm{Cd}$ in rice is still unclear [24]. In root, OsZIP7 plays a role in loading Cd into xylem (Figure 1). A knockout of OsZIP7 leads to the accumulation of large amounts of $\mathrm{Cd}$ in roots, decreasing $\mathrm{Cd}$ content in the grains [31].

Shimo et al. [25] screened the rice transfer DNA (T-DNA) mutant library for sequences related to $\mathrm{Cd}$ tolerance and obtained the $\mathrm{Cd}$-resistant mutant $l c d$. The $l c d$ seedlings grown on agar plates or in hydroponic culture exhibited increased tolerance of $\mathrm{Cd}$ toxicity. This 
study demonstrates that OsLCD is strongly expressed in root vascular bundles and OsLCD is involved in regulating the transport of $\mathrm{Cd}$ from the root to the shoot in rice. The knockout of OsLCD reduced the concentration of $\mathrm{Cd}$ in rice aerial organs and promoted rice growth under Cd stress. In addition, OsLCD is also expressed in phloem companion cells of leaves, suggesting the possibility that OsLCD is involved in regulating $\mathrm{Cd}$ transport from the leaf to the stem node through the phloem.

The transporter OsHMA2 is reported to mainly localize in the root pericycle cells of rice (Figure 1), and it plays a role in the xylem loading of $\mathrm{Cd}$ [24]. Compared to the wild type, the loss-of-function mutant of OsHMA2 shows significant inhibition of $\mathrm{Cd}$ transport from the root to the shoot [26,27]. In addition, the OsHMA2 gene is expressed in the phloem parenchyma cells of enlarged and diffuse vascular bundles of the stem node during the reproductive stage (Figure 2), which in turn increases the amount of $\mathrm{Cd}$ transported through the phloem. It has been confirmed that the concentration of $\mathrm{Cd}$ in OsHMA2-supressed rice leaves and grains is lower than that in wild type [26-28].

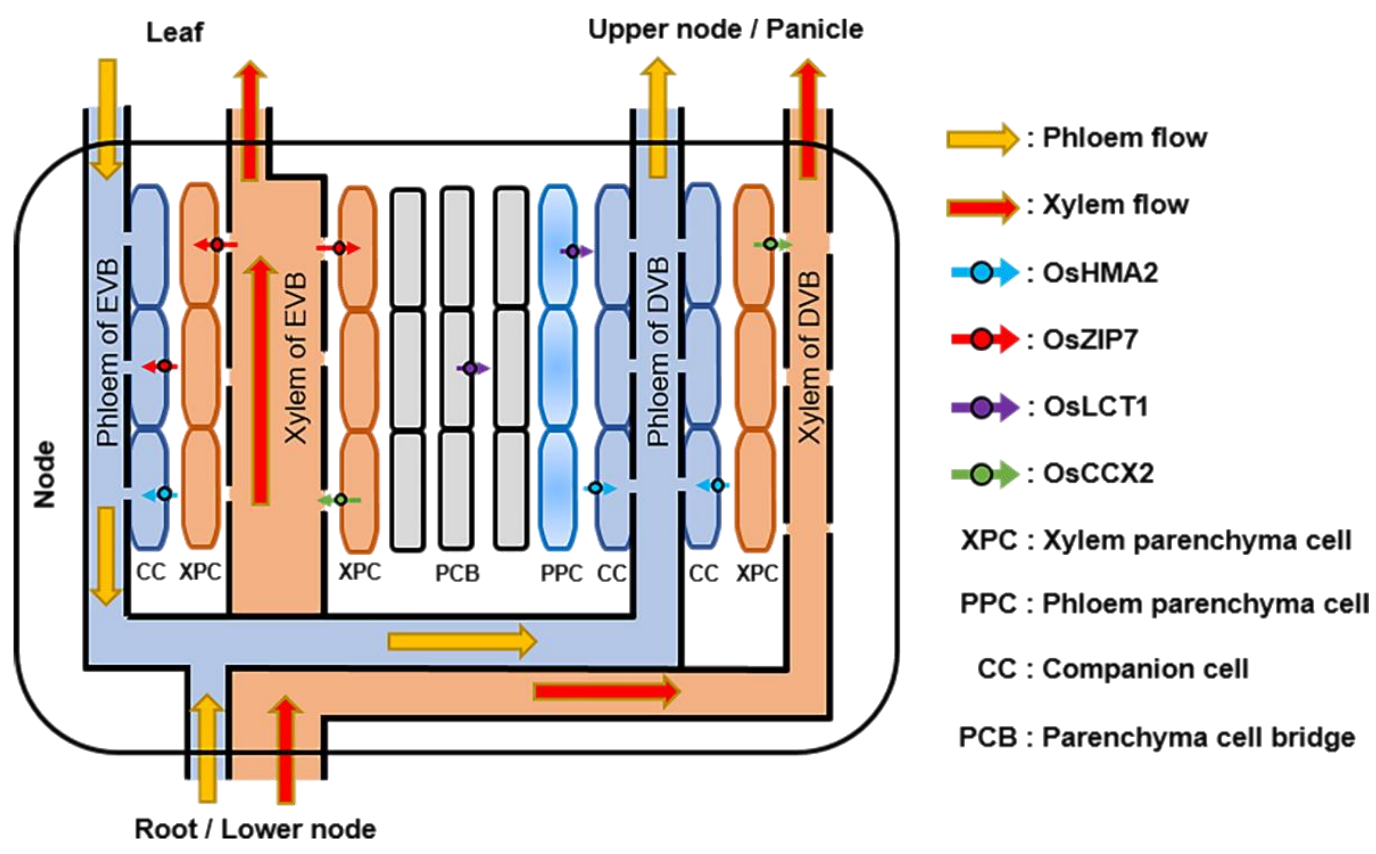

Figure 2. Schematic diagram of Cd transport in rice nodes. OsHMA2, localized in the phloem parenchyma and companion cells of both enlarged and diffuse vascular bundles in stem nodes, mediates the loading of $\mathrm{Cd}$ into the phloem for the preferential distribution to the upper nodes and panicle. OsZIP7, localized in both xylem and phloem parenchyma cells of the enlarged vascular bundles, can transport the $\mathrm{Cd}$ from xylem to phloem and unload $\mathrm{Cd}$ from xylem to parenchyma cell bridge. OsLCT1, localized in parenchyma cell bridge and phloem parenchyma cells of diffuse vascular bundles, mediates the intervascular transfer of $\mathrm{Cd}$ and promotes the transport of $\mathrm{Cd}$ to the grain through phloem. OsCCX2, localized in the xylem parenchyma cells of enlarged and diffuse vascular bundles, mediates the loading of $\mathrm{Cd}$ into the xylem and promotes $\mathrm{Cd}$ transport into grains.

CAL1, a major quantitative trait locus gene that specifically regulates $\mathrm{Cd}$ accumulation in rice leaves, has been cloned. CAL1 is mainly localized to the root and the leaf sheath xylem parenchyma cells and can specifically chelate $\mathrm{Cd}$ with its three thiol groups, after which the $\mathrm{Cd}$ chelate is secreted into the xylem vessel and transported to the aerial vegetative organs, thereby increasing the Cd contents in rice straw and leaves (Figure 1) [29]. It has been reported that up-regulation of CAL1 can increase Cd accumulation in rice leaves. However, due to the tight binding of CAL1 to $\mathrm{Cd}$, the transmembrane transport of $\mathrm{Cd}$ chelate into the phloem is prevented, and consequently, the transport of $\mathrm{Cd}$ from straw to grains is not promoted. Thus, up-regulation of CAL1 cannot increase Cd accumulation in rice grains [29]. 
OsMTP1, a transporter expressed in the root, the stem and the leaf, plays an important role in Cd transport [30]. Previous study demonstrated that when double-strand RNA interference (dsRNAi) plants of OsMTP1 were under Cd stress, the Cd content in the root was higher than that in the wild type, while Cd content in the shoot was lower than that in the wild type. These results suggest that down-regulation of OsMTP1 might impair Cd transport from roots to shoots. In addition, in the leaf, OsMTP1 is specifically expressed in sieve tube cells (Figure 2) [30], suggesting the possibility that OsMTP1 is involved in the mediation of $\mathrm{Cd}$ transport through the phloem in the leaf.

\subsection{Cd Transport from Vegetative Organs to Grains}

At the vegetative stage, the root-absorbed $\mathrm{Cd}$ is transported to the unelongated basal internodes mainly through the xylem and is then transported to the leaves through the xylem of the enlarged vascular bundle. During the early period of grain development, some of the $\mathrm{Cd}$ in leaves is reactivated and transported to stem nodes through the phloem and is then transported to grains through the phloem of the diffuse vascular bundle (Figure 2) $[28,32,65,66]$. Moreover, during the reproductive stage, some of the root-absorbed $\mathrm{Cd}$ is transported to the lower nodes through xylem and transported to the uppermost node through xylem and phloem; it is then transported to the grains through the phloem of the diffuse vascular bundles [28]. In addition, during the filling stage, a small amount of root-absorbed $\mathrm{Cd}$ is able to be transported to the stem and then directly transported to the grain through the xylem [32]. Once $\mathrm{Cd}$ is transported to the grain, it is fixed in the grain and is not further transported to other organs. At least $91 \%$ of $\mathrm{Cd}$ enters rice grains through the phloem [67], indicating that phloem transport plays an important role in $\mathrm{Cd}$ accumulation in rice grains. The above results show that $\mathrm{Cd}$ absorbed by roots is mainly transported to the aerial part through the xylem, while Cd enters grains mainly through the phloem, which indicates that most of the $\mathrm{Cd}$ needs to be transferred from the xylem to the phloem before being transported to grains.

It has been demonstrated that the stem node is an important organ that regulates the transfer of $\mathrm{Cd}$ from xylem to phloem, and the transfer process occurs in the enlarged and diffuse vascular bundles of the stem node [28,31,65]. In stem nodes, OsZIP7 is expressed in both the xylem and phloem parenchyma cells of the enlarged vascular bundle, which can facilitate the transfer of $\mathrm{Cd}$ from xylem to phloem (Figure 2, Table 1) [31]. Moreover, in stem nodes, $\mathrm{Cd}$ is able to be transferred between different vascular bundles, and $\mathrm{Cd}$ in the xylem of the enlarged vascular bundle is able to be transferred to the phloem of the diffuse vascular bundle [28,65]. Previous results demonstrated that three Cd transport genes, OsLCT1, OsZIP7 and OsHMA2, can express in stem nodes, and they may promote the transfer of $\mathrm{Cd}$ between vascular bundles in stem nodes. OsZIP7, which is expressed in xylem parenchyma cells of enlarged vascular bundles in stem nodes, is responsible for unloading $\mathrm{Cd}$ from the xylem of enlarged vascular bundles to the parenchyma cell bridge [31]. OsLCT1 can express in the parenchyma cell bridge (several layers of cells between the enlarged vascular bundles and the diffuse vascular bundles), and OsLCT1 may mediate the transport of $\mathrm{Cd}$ between the parenchyma cell bridge and the phloem parenchyma cells of diffuse vascular bundle [33]. In the diffuse vascular bundle of the stem node, OsHMA2 can load Cd from the phloem parenchyma cell to the phloem sieve [28]. These results indicate that OsLCT1, OsZIP7 and OsHMA2 may act synergistically to promote the transfer of $\mathrm{Cd}$ from enlarged to diffuse vascular bundles in stem nodes.

In addition, OsLCT1 has been described as a transporter that is highly expressed in the phloem plasma membrane of the vascular bundles in the uppermost node [33]. It has been reported that the expression level of OsLCT1 in the uppermost node at the grain maturity stage is about 100 times higher than that at the heading stage and that grain maturity is the key stage for $\mathrm{Cd}$ accumulation in rice grains [33]. The down-regulation of the OsLCT1 gene does not affect the transport of $\mathrm{Cd}$ in xylem but significantly inhibits its transport in phloem and decreases its content in rice grains. RNA interference of OsLCT1 expression has no negative effect on rice growth or the contents of other metals and mineral elements in rice 
grains. All this evidence suggests that, at the grain maturity stage, OsLCT1 is a crucial transporter for $\mathrm{Cd}$ transport from the uppermost node to rice grains (Figure 2, Table 1).

It has been reported that OsCCX2 can promote an upward transport of $\mathrm{Cd}$ in xylem (Figure 2, Table 1), and a knockout of the OsCCX2 gene reduces the transfer rate of Cd from roots to the aerial organs. OsCCX2 is mainly expressed in the xylem parenchyma cells of enlarged and diffuse vascular bundles in the stem node. OsCCX2 can load Cd into xylem vessels of diffuse vascular bundles and mediate $\mathrm{Cd}$ transport into grains through the xylem transport system of diffuse vascular bundles. The loss-of-function mutant of OsCCX2 significantly reduces the accumulation of $\mathrm{Cd}$ in grains [32]. In addition, OsCCX2 can also load $\mathrm{Cd}$ into xylem vessels of enlarged vascular bundles and mediate $\mathrm{Cd}$ transport into leaves through the xylem of enlarged vascular bundles.

Differences in $\mathrm{Cd}$ accumulation have been reported among rice subspecies. Previous results have demonstrated that $\mathrm{OsCd} 1$ is expressed in root cortex cells and root stele cells at the vegetative stage, and it can mediate the uptake of $\mathrm{Cd}$ by rice roots and may also participate in the transport of $\mathrm{Cd}$ from the root xylem to the aerial part, thus affecting the accumulation of $\mathrm{Cd}$ in the aerial organs of rice, including straw and grains [21]. The contents of $\mathrm{Cd}$ in the straw and grains of the loss-of-function mutant of OsCd1 are significantly decreased, and the growth and grain yield of the mutant are also severely reduced. Usually, the $\mathrm{Cd}$ content in indica rice grains is higher than that in japonica rice grains [68]. However, indica rice varieties carrying the japonica rice allele OsCd1 ${ }^{\mathrm{v} 449}$ exhibit reduced Cd accumulation in grains, with almost no effect on growth or grain yield [21]. This evidence indicates that identifying and utilizing useful alleles of OsCd1 and other $\mathrm{Cd}$ accumulation-related genes may be an effective method to reduce $\mathrm{Cd}$ accumulation in rice grains.

\section{Rice Resistance to Cd}

To adapt to the Cd-contaminated soil environment, rice plants have evolved various strategies to resist $\mathrm{Cd}$ toxicity, including $\mathrm{Cd}$ deposition in cell wall, vacuolar sequestration, chelation, antioxidation and efflux [69-71].

\subsection{Cd Deposition in the Cell Wall}

The cell wall is the first defensive structure of plant cells to respond to adverse environmental conditions, such as Cd contamination [72]. After Cd enter the plant, some become attached to the cell wall, which prevents excessive $\mathrm{Cd}$ from reaching the cytoplasm, thereby protecting the cell from damage [72]. Root cell walls play an important role in this process, as the root is the organ most directly exposed to $\mathrm{Cd}$ in soil. In roots, $\mathrm{Cd}$ accumulation in the outer epidermal layer is usually more than that in cortical tissues [73]. When the concentration of $\mathrm{Cd}$ in the soil is low, most $\mathrm{Cd}$ taken up by plants is stored in the cell walls of roots [7]. Cd deposition in the cell wall will increase the content of $\mathrm{Cd}$ in rice roots, which in turn will decrease $\mathrm{Cd}$ content in the shoot by limiting the transport of $\mathrm{Cd}$ from the root to the shoot [72]. Similarly, increased $\mathrm{Cd}$ deposition in the cell walls of aerial vegetative organs will reduce the transport of $\mathrm{Cd}$ from these organs to the grains [34]. Previous result suggests that OsCDT1 may play an important role in increasing the resistance of rice to Cd toxicity (Table 1) [74]. OsCDT1 is reportedly targeted at both the cytoplasmic membranes and cell walls of plant cells, and OsCDT1 can chelate $\mathrm{Cd}$ on the cell surface, limiting Cd entry into the cell. Transgenic Arabidopsis plants overexpressing OsCDT1 accumulate less $\mathrm{Cd}$ than wild-type plants, and they display a Cd-tolerant phenotype [74].

After entering the root system, $\mathrm{Cd}$ is first fixed to the root cell wall by carbohydrates, which is the first barrier against $\mathrm{Cd}$ toxicity. The cell wall has a strong ability to adsorb $\mathrm{Cd}$, which can prevent $\mathrm{Cd}$ from entering cells and improve the $\mathrm{Cd}$ stress resistance of plants. Pectin is an important $\mathrm{Cd}$ binding site in the cell wall, and rice cell walls with higher pectin contents adsorb Cd more quickly and exhibit greater Cd tolerance [75,76].

In contrast, a previous study revealed that heterologous overexpression of Populus euphratica PeXTH in tobacco reduced Cd accumulation in the cell and alleviated Cd toxicity 
by reducing the $\mathrm{Cd}$ binding sides on the cell wall [77]. It has been reported that xyloglucan endotransglucosylase/hydrolase $(\mathrm{XTH})$ can alleviate $\mathrm{Cd}$ toxicity by decreasing $\mathrm{Cd}$ accumulation in plant root through the reduced Cd binding sites on the root cell wall [77]. Overexpression of $\mathrm{PeXTH}$ in tobacco promoted the degradation of xyloglucan, reduced the amount of xyloglucan in the cell wall and led to a decrease in Cd binding sites, thereby reducing $\mathrm{Cd}$ content of the cell wall, which in turn alleviated $\mathrm{Cd}$ toxicity in the transgenic tobacco plant [77].

\subsection{Vacuolar Sequestration}

In 2010, two research groups independently cloned OsHMA3, a gene that encodes a transporter (Table 1) [35,36]. OsHMA3 localizes on the vacuolar membrane and plays an important role in alleviating $\mathrm{Cd}$ toxicity in rice (Figure 1). OsHMA3 transports $\mathrm{Cd}$ from the cytoplasm to the vacuole, which in turn prevents transmembrane transport of $\mathrm{Cd}$ into the xylem. The down-regulation of OsHMA3 enhances $\mathrm{Cd}$ translocation to rice shoots, while its overexpression reduces $\mathrm{Cd}$ contents of the rice shoots and grains and alleviates $\mathrm{Cd}$ toxicity in OsHMA3-OE lines [35,36]. A loss-of-function mutation of the allele of OsHMA3 present in japonica rice varieties is the main reason for high accumulation of $\mathrm{Cd}$ in the seedlings and grains of some japonica varieties [37,78]. Other genes homologous to HMA3 may have the same function. For example, AtHMA3, one of the closest homologs of OsHMA3, can transport $\mathrm{Cd}$ and $\mathrm{Zn}$ in Arabidopsis and maintain $\mathrm{Cd}$ and $\mathrm{Zn}$ within the vacuoles [79]. In addition, in the Cd/Zn hyperaccumulator Sedum plumbizincicola, SpHMA3 plays a key role in mediating vacuolar $\mathrm{Cd}$ sequestration and Cd detoxification [80].

An ABC-type transporter, OsABCG43, may play a role in the sequestration of $\mathrm{Cd}$ into subcellular organelles, thereby reducing $\mathrm{Cd}$ toxicity (Table 1) [38]. In addition, the transport of Cd complex into vacuoles is another important detoxification pathway. The SpHMT1 transporter transports $\mathrm{Cd}$ complexes to vacuoles, and overexpression of SpHMT1 can significantly increase $\mathrm{Cd}$ tolerance in transgenic yeast [81]. In Arabidopsis, three ABCC-type transporters, AtABCC1, AtABCC2 and AtABCC3, have been reported to improve tolerance of $\mathrm{Cd}$ by transferring phytochelatin (PC)-Cd chelates from the cytoplasm to the vacuoles, and a knockout of these genes causes a hypersensitive response of Arabidopsis to Cd [82,83]. AtABCC1 and AtABCC2 can also increase the tolerance of Arabidopsis to mercury $(\mathrm{Hg})$ by transferring $\mathrm{PC}-\mathrm{Hg}$ chelates from the cytoplasm to the vacuoles [82]. However, the transporters that can transport PC-Cd and PC-Hg chelates into vacuoles have not yet been identified in rice.

\subsection{Chelation}

The chelation of $\mathrm{Cd}$ plays an important role in plant tolerance of $\mathrm{Cd}$ toxicity. Chelating agents in plants can prevent contact between $\mathrm{Cd}$ and organelles through $\mathrm{Cd}$ chelation and impede biochemical reactions between $\mathrm{Cd}$ and other substances, thereby reducing Cd toxicity [39,84-86].

Glutathione (GSH) is a tripeptide that can form an active transport complex of bis (glutathionato) cadmium (Cd.GS 2 ) (Figure 1). Yeast cadmium factor 1 (YCF1) is able to transport $\mathrm{Cd} \cdot \mathrm{GS}_{2}$ into the vacuoles, thus reducing the toxicity of $\mathrm{Cd}$ to plants [85]. PC is a Cd-binding peptide that is synthesized using GSH as substrate and catalyzed by PC synthetase. Cysteine synthesis is the rate-limiting step of PC synthesis, and transgenic plants expressing the rice cysteine synthase gene OsRCS1 have increased Cd tolerance compared to wild-type plants (Table 1) [40]. Moreover, overexpression of the rice PC synthesis genes OsPCS5 and OsPCS15 in ycf1, a loss-of-function mutant of YCF1, can enhance the resistance of $y c f 1$ to $C d$ toxicity (Table 1) [41].

Binding peptides can bind $90 \%$ of the $\mathrm{Cd}$ taken up by plants, providing resistance against Cd toxicity [84]. The Arabidopsis mutant cad1, which lacks PC synthase activity, is hypersensitive to $\mathrm{Cd}$ [87]. PC can chelate $\mathrm{Cd}$, thus reducing damage to the photosynthetic system of Brassica juncea caused by Cd [88]. Overexpression of the Arabidopsis PC synthase gene AtPCS in rice significantly enhances tolerance of $\mathrm{Cd}$ [89]. In addition, the expression 
of the wheat PC synthase gene TaPCS1 in tobacco and the Arabidopsis PC synthase gene AtPCS1 in Brassica juncea increases PC synthesis and enhances the tolerance of both transgenic plants of $\mathrm{Cd}[90,91]$. High salinity and Cd stresses can synergistically up-regulate the expression of PCS1 in semi-halophyte Mesembryanthemum crystallinum and promote PC synthesis and enhance the resistance of halophytes to Cd under high salinity $[19,20]$. In contrast, overexpression of OsPCS5 and OsPCS15 in transgenic Arabidopsis results in a hypersensitive response to $\mathrm{Cd}$ and reduces resistance to $\mathrm{Cd}$ [41]. Similarly, overexpression of AtPCS1 in tobacco and TaPCS1 in rice also leads to hypersensitive responses of transgenic plants to $\mathrm{Cd}$, along with reduced resistance to $\mathrm{Cd}[92,93]$. Taken together, these findings show that overexpression of the same PC synthase gene in different plant species may lead to different degrees of $\mathrm{Cd}$ resistance, and overexpression of different PC synthase genes in the same plant species may also lead to differences in Cd resistance. Possible explanations for these differences among plant species and PC synthase genes include the cells of different plant species having different microenvironments, the enzymes produced due to overexpression of PC synthase genes exhibiting different enzyme activities and ectopic expression levels of different PC synthase genes being different, even within a plant species [92]. In addition, although PC content is closely correlated with the accumulation of $\mathrm{Cd}$ in vivo $[89,93,94]$, the threshold level of $\mathrm{Cd}$ accumulation in vacuoles may differ among species, which may lead to differences in $\mathrm{Cd}$ resistance.

Plant roots can secrete citric acid into the soil, which can increase the availability of $\mathrm{Cd}$ in soil and thus promote the absorption of $\mathrm{Cd}$ by plants. On the other hand, citric acid can chelate free $\mathrm{Cd}$ ions and reduce their toxic effects on plants, as well as enhance the activities of antioxidant enzymes and alleviate the lipid peroxidation induced by $\mathrm{Cd}$ stress $[86,95,96]$. In addition, some organic compounds such as humic acid will chelate with $\mathrm{Cd}$ in the process of vascular transport of $\mathrm{Cd}$, thus affecting the bioavailability of $\mathrm{Cd}[97,98]$.

OsHsfA4a can induce the expression of the metallothionein (MT) gene and thus enhance the tolerance of rice to Cd via the chelation between MT and Cd (Table 1) [39]. The expression of the rice rgMT gene in Escherichia coli (E. coli) enhances the Cd resistance of transgenic E. coli (Table 1) [42].

\subsection{Antioxidation}

When rice is exposed to $\mathrm{Cd}$ stress, it produces excessive quantities of reactive oxygen species (ROS), such as superoxide anion radicals, hydrogen peroxide and hydroxyl radicals. Excessive ROS disrupt the redox balance of rice plants, leading to a dysfunction of the antioxidant system, which in turn causes membrane lipid peroxidation and other types of oxidative damage, including programed cell death [99].

GSH plays important roles during the antioxidation process of rice exposed to $\mathrm{Cd}$. It has been reported that glutathione synthetase (GS) is an important enzyme involved in catalyzing GSH biosynthesis, and the overexpression of the gene encoding $\gamma$-glutamylcysteine synthetase ( $\gamma$-ECS) and the gshII gene encoding GS from E. coli in Brassica juncea promotes glutathione synthesis and enhances Cd tolerance of transgenic Brassica juncea $[100,101]$. Previous studies demonstrated that overexpression of the $\gamma$-ECS can also strengthen Arabidopsis resistance to arsenic [102]. GSH can remove excessive ROS and bind Cd, effectively reducing the toxic effects of $\mathrm{Cd}$ on rice [103]. Moreover, GSH can enter the nucleus during cell division and proliferation to regulate the cell cycle, and it can also remove ROS directly or indirectly, thus playing an important role in maintaining the redox homeostasis of cells [104]. In addition, GSH can inhibit lipid peroxidation through the GSH peroxidase and GSH reductase system, thereby protecting cell membrane, and it can directly reduce lipid free radicals and lipid peroxide free radicals to block the chain reaction of lipid peroxidation [105]. In addition, salinity stress can enhance the activities of antioxidative enzymes catalase and GSH peroxidase to alleviate the oxidative stress caused by Cd toxicity [106].

Previous report demonstrated that OsCLT1, which is localized to plastids, can regulate the $\mathrm{Cd}$ tolerance of rice plants by alleviating the oxidative stress via the promotion of GSH biosynthesis (Table 1) [43]. The loss-of-function mutation of OsCLT1 led to decreased 
GSH and PC concentrations in root cells of mutant rice, resulting in hypersensitivity to $\mathrm{Cd}$ [43]. Agrawal et al. [44] suggested that ROS induced by Cd toxicity, particularly $\mathrm{H}_{2} \mathrm{O}_{2}$, regulates antioxidant activity in rice plants by inducing the expression of OsMSRMK 3 and OsWJUMK1 (Table 1).

It has been reported that jasmonic acid, jasmonoyl-isoleucine, methyl jasmonate and 12-oxygen phthalate acid (a jasmonic acid precursor) are signal molecules involved in the regulation of rice growth and stress responses [107]. Methyl jasmonate can reduce the absorption of $\mathrm{Cd}$ and increase the activities of antioxidant enzymes, such as peroxidase, superoxide dismutase, catalase and glutathione reductase, which in turn reduces excessive hydrogen peroxide and superoxide anion free radicals, thereby reducing oxidative damage caused by $\mathrm{Cd}$ to rice seedlings [108]. In addition, the OsAUX1 gene can regulate the growth of primary roots and root hairs and improve the capacity to resist oxidative stress under $\mathrm{Cd}$ exposure (Table 1), and thus a loss-of-function mutant of OsAUX1 in rice exhibits severe oxidative damage due to Cd exposure [45].

\subsection{Efflux}

OsHMA9, which encodes a heavy metal efflux transporter that is located in the plasma membrane, has $\mathrm{Cd}, \mathrm{Cu}, \mathrm{Zn}$ and $\mathrm{Pb}$ efflux activities (Figure 1, Table 1). A knockout of the OsHMA9 gene results in greater accumulation of $\mathrm{Cd}$ in mutant plants compared to wild-type plants, which in turn leads to a hypersensitive response of the mutant to Cd [46]. Moreover, plant ZIP proteins (zinc and iron transporters), a family of metal transporters, are involved in the absorption and distribution of $\mathrm{Zn}$ and $\mathrm{Cd}$. OsZIP1, a transporter that is widely expressed in rice roots (Table 1), plays an important role in metal detoxification and prevents the excessive accumulation of $\mathrm{Zn}, \mathrm{Cu}$ and $\mathrm{Cd}$ in rice. When $\mathrm{Zn}, \mathrm{Cu}$ and $\mathrm{Cd}$ levels in the environment are excessive, OsZIP1 acts as a metal efflux transporter from rice cells [47]. In addition, OsABCG36/OsPDR9, a G-type ATP-binding transporter, is involved in Cd resistance in rice (Table 1) [48]. It has been confirmed that OsABCG36 is localized to the plasma membrane by using a transient expression system in rice protoplast, and $\mathrm{Cd}$ could significantly induce the expression of OsABCG36 in mature root zones, as well as root tips. Under high $\mathrm{Cd}$ stress conditions, compared to the wild type, the accumulation of $\mathrm{Cd}$ in the root cell sap of OsABCG36 knockout rice was significantly elevated, as was sensitivity to $\mathrm{Cd}$, but the accumulation of $\mathrm{Cd}$ in aerial organs was essentially unchanged. This pattern indicated that OsABCG36 is not involved in the accumulation of Cd in aerial organs, but instead enhances the resistance of rice to $\mathrm{Cd}$ by promoting the efflux of $\mathrm{Cd}$ or Cd conjugates from root cells [48].

\section{Conclusions and Perspectives}

$\mathrm{Cd}$ pollution of farmland is a serious problem. In recent decades, scientists have made many important advances in understanding $\mathrm{Cd}$ uptake, transport and resistance in rice, but some of the molecular mechanisms underlying these processes are still unknown. Previous reports indicated that the expression of OsCd1 in the root cortex may promote the absorption of $\mathrm{Cd}$ by rice roots, but it is unclear whether the expression of OsCd1 in the root stele can facilitate the transport of $\mathrm{Cd}$ from the root to the shoot by promoting $\mathrm{Cd}$ loading. OsCDT1 is located in the cytoplasmic membrane and can restrict the entry of $\mathrm{Cd}$ into cells by chelating $\mathrm{Cd}$ on the cell surface, thereby enhancing the tolerance of plants to Cd. However, the chelation site for Cd on OsCDT1 has not yet been reported, and the chelation mechanism has not been well studied. Although PC plays an important role in the process of $\mathrm{Cd}$ chelation and the mitigating of $\mathrm{Cd}$ toxicity, overexpression of PC synthase genes leads to increased Cd tolerance in some plants and decreased Cd tolerance in others, and the different mechanisms for these opposite effects need further confirmation. Previous studies have shown that loss-of-function mutation of OsAUX1 results in increased $\mathrm{Cd}$ sensitivity due to the severe oxidative damage in the rice mutant under $\mathrm{Cd}$ exposure, but the regulatory mechanism of OsAUX1 in the antioxidation process under $\mathrm{Cd}$ exposure remains unclear. OsABCG36 promotes $\mathrm{Cd}$ efflux from rice roots, thereby 
improving resistance to $\mathrm{Cd}$. However, the form (ionic or chelated) of $\mathrm{Cd}$ that is excreted due to OsABCG36 remains unknown, and the molecular mechanism through which OsABCG36 promotes $\mathrm{Cd}$ efflux has not yet been elucidated.

The Cd content in indica rice grains is generally higher than that in japonica rice grains [71], and indica rice varieties that carry the japonica rice allele OsCd1 ${ }^{\mathrm{v} 44}$ exhibit reduced $\mathrm{Cd}$ accumulation in grains [22]. Loss-of-function mutation of the OsHMA3 alleles in japonica rice varieties is the main reason for the accumulation of $\mathrm{Cd}$ in the grains of some japonica rice varieties $[81,82]$. However, whether natural variation in other genes also contributes to the differences in $\mathrm{Cd}$ content between the indica and japonica rice varieties remains obscure. Moreover, the transport of $\mathrm{Cd}$ and $\mathrm{Cd}$ complexes into vacuoles is also an important detoxification method. However, the transporters that can transport $\mathrm{Cd}$ complexes such as PC-Cd and Cd.GS 2 into the vacuoles of rice cells have not been identified. In future research, the unresolved scientific questions concerning $\mathrm{Cd}$ uptake, transport and resistance in rice may be revealed through the construction of mutants and use of molecular, genetic, physiological and multi-omics techniques, and bioinformatics. In addition, it is of great significance to identify unknown genes, which are related to $\mathrm{Cd}$ uptake, transport and resistance in rice, and to investigate the functional mechanisms of these genes. Additionally, with the intensification of climate change, the decomposition of soil organic matter is also strengthening [109], which may lead to an increase in Cd bioavailability in soil and may increase $\mathrm{Cd}$ toxicity to rice. The underlying mechanism by which climate change affects $\mathrm{Cd}$ bioavailability in soil needs further investigation. The research progress in this field can be used to reduce the $\mathrm{Cd}$-caused yield loss by enhancing rice resistance to $\mathrm{Cd}$ toxicity, produce safe rice grains by reducing $\mathrm{Cd}$ accumulation in rice grains and repair the $\mathrm{Cd}$-contaminated paddy fields by cultivating and planting rice varieties with strong $\mathrm{Cd}$ enrichment.

Author Contributions: Conceptualization, J.Z. and C.Y.; investigation, J.Z.; Writing-Original draft, J.Z. and Y.Z.; methodology, Y.Z.; visualization, Y.Z.; formal analysis, X.Z.; validation, L.Y.; WritingReview and editing, M.Y. and C.Y.; supervision, C.Y. and Y.L.; funding acquisition, C.Y.; project administration, Y.L. All authors have read and agreed to the published version of the manuscript.

Funding: This work was funded by the Natural Science Foundation of Hubei Province of China (No. 2016CFB436), the National Key Research and Development Program of China (No. 2016YFD0300102), the Science and Technology Major Projects of Guangxi Province of China (GuiKeChuang 010106), and the Postdoctoral Science Foundation of China (No. 2016T90705).

Acknowledgments: We thank Xie Zhou (Nanjing Agricultural University, China) and Shaobing Peng (Huazhong Agricultural University, China) for providing valuable assistance and advice for this work.

Conflicts of Interest: The authors declare no conflict of interest.

\section{References}

1. Yang, S.; Zhou, D.; Yu, H.; Wei, R.; Pan, B. Distribution and speciation of metals (Cu, Zn, Cd, and Pb) in agricultural and non-agricultural soils near a stream upriver from the Pearl River, China. Environ. Pollut. 2013, 177, 64-70. [CrossRef] [PubMed]

2. Zhang, Y.P.; Wang, L. Molecular mechanism of rice responses to cadmium stress. Chin. J. Rice Sci. 2013, 27, 539-544. [CrossRef]

3. Zhai, L.; Liao, X.; Chen, T.; Yan, X.; Xie, H.; Wu, B.; Wang, L. Regional assessment of cadmium pollution in agricultural lands and the potential health risk related to intensive mining activities: A case study in Chenzhou City, China. J. Environ. Sci. 2008, 20, 696-703. [CrossRef]

4. Song, Y.; Wang, Y.; Mao, W.; Sui, H.; Yang, L.; Yang, D.; Jiang, D.; Zhang, L.; Gong, Y. Dietary cadmium exposure assessment among the Chinese population. PLoS ONE 2017, 12, e0177978. [CrossRef]

5. Tang, L.; Mao, B.; Li, Y.; Lv, Q.; Zhang, L.; Chen, C.; He, H.; Wang, W.; Zeng, X.; Shao, Y.; et al. Knockout of OsNramp5 using the CRISPR/Cas9 system produces low Cd-accumulating indica rice without compromising yield. Sci. Rep. UK 2017, 7, 14438. [CrossRef]

6. Seregin, I.V.; Kozhevnikova, A.D. Roles of root and shoot tissues in transport and accumulation of cadmium, lead, nickel, and strontium. Russ. J. Plant Physiol. 2008, 55, 1-22. [CrossRef]

7. Belleghem, F.V.; Cuypers, A.; Semane, B.; Smeets, K.; Vangronsveld, J.; d'Haen, J.; Valcke, R. Subcellular localization of cadmium in roots and leaves of Arabidopsis thaliana. New Phytol. 2007, 173, 495-508. [CrossRef]

8. Wang, X.; Wang, W.; Yang, L.; Wang, X.; Wang, W.; Yang, L.; Jin, L.; Song, Y.; Jiang, S.; Qin, L. Transport pathways of cadmium (Cd) and its regulatory mechanisms in plant. Acta Ecol. Sin. 2015, 35, 7921-7929. [CrossRef] 
9. Sasaki, A.; Yamaji, N.; Yokosho, K.; Ma, J.F. Nramp5 is a major transporter responsible for manganese and cadmium uptake in rice. Plant Cell 2012, 24, 2155-2167. [CrossRef]

10. Ishikawa, S.; Ishimaru, Y.; Igura, M.; Kuramata, M.; Abe, T.; Senoura, T.; Hase, Y.; Arao, T.; Nishizawa, N.K.; Nakanishi, H Ion-beam irradiation, gene identification, and marker-assisted breeding in the development of low-cadmium rice. Proc. Natl. Acad. Sci. USA 2012, 109, 19166-19171. [CrossRef]

11. Chang, J.D.; Huang, S.; Konishi, N.; Wang, P.; Chen, J.; Huang, X.Y.; Ma, J.F.; Zhao, F.J. Overexpression of the manganese/cadmium transporter OsNRAMP5 reduces cadmium accumulation in rice grain. J. Exp. Bot. 2020, 71, 5705-5715. [CrossRef]

12. Takahashi, R.; Ishimaru, Y.; Senoura, T.; Shimo, H.; Ishikawa, S.; Arao, T.; Nakanishi, H.; Nishizawa, N.K. The OsNRAMP1 iron transporter is involved in Cd accumulation in rice. J. Exp. Bot. 2011, 62, 4843-4850. [CrossRef]

13. Chang, J.D.; Huang, S.; Yamaji, N.; Zhang, W.; Ma, J.F.; Zhao, F.J. OsNRAMP1 contributes to cadmium and manganese uptake in rice. Plant Cell Environ. 2020, 43, 2476-2491. [CrossRef]

14. Takahashi, R.; Ishimaru, Y.; Nakanishi, H.; Nishizawa, N.K. Role of the iron transporter OsNRAMP1 in cadmium uptake and accumulation in rice. Plant Signal. Behav. 2011, 6, 1813-1816. [CrossRef]

15. Lee, S.; An, G. Over-expression of OsIRT1 leads to increased iron and zinc accumulations in rice. Plant Cell Environ. 2009, 32, $408-416$. [CrossRef]

16. Nakanishi, H.; Ogawa, I.; Ishimaru, Y.; Mori, S.; Nishizawa, N.K. Iron deficiency enhances cadmium uptake and translocation mediated by the $\mathrm{Fe}^{2+}$ transporters OsIRT1 and OsIRT2 in rice. Soil Sci. Plant Nutr. 2006, 52, 464-469. [CrossRef]

17. Ishimaru, Y.; Suzuki, M.; Tsukamoto, T.; Suzuki, K.; Nakazono, M.; Kobayashi, T.; Wada, Y.; Watanabe, S.; Matsuhashi, S.; Takahashi, M.; et al. Rice plants take up iron as an $\mathrm{Fe}^{3+}$-phytosiderophore and as Fe ${ }^{2+}$. Plant J. 2006, 45, 335-346. [CrossRef]

18. Ishimaru, Y.; Kakei, Y.; Shimo, H.; Bashir, K.; Sato, Y.; Sato, Y.; Uozumi, N.; Nakanishi, H.; Nishizawa, N.K. A rice phenolic efflux transporter is essential for solubilizing precipitated apoplasmic iron in the plant stele. J. Biol. Chem. 2011, 286, 24649-24655. [CrossRef]

19. Ondrasek, G.; Rengel, Z.; Maurovic, N.; Kondres, N.; Filipovic, V.; Savic, R.; Blagojevic, B.; Tanaskovik, V.; Gergichevich, C.M.; Romic, D. Growth and element uptake by salt-sensitive crops under combined $\mathrm{NaCl}$ and Cd stresses. Plants 2021, 10, 1202 [CrossRef]

20. Nosek, M.; Kaczmarczyk, A.; Jedrzejczyk, R.J.; Supel, P.; Kaszycki, P.; Miszalski, Z. Expression of genes involved in heavy metal trafficking in plants exposed to salinity stress and elevated Cd concentrations. Plants 2020, 9, 475. [CrossRef]

21. Yan, H.; Xu, W.; Xie, J.; Gao, Y.; Wu, L.; Sun, L.; Feng, L.; Chen, X.; Zhang, T.; Dai, C.; et al. Variation of a major facilitator superfamily gene contributes to differential cadmium accumulation between rice subspecies. Nat. Commun. 2019, 10, 2562 [CrossRef]

22. Ramesh, S.A.; Shin, R.; Eide, D.J.; Schachtman, D.P. Differential metal selectivity and gene expression of two zinc transporters from rice. Plant Physiol. 2003, 133, 126-134. [CrossRef] [PubMed]

23. Lim, S.D.; Hwang, J.G.; Han, A.R.; Park, Y.C.; Lee, C.; Ok, Y.S.; Jang, C.S. Positive regulation of rice RING E3 ligase OsHIR1 in arsenic and cadmium uptakes. Plant Mol. Biol. 2014, 85, 365-379. [CrossRef] [PubMed]

24. Kavitha, P.G.; Kuruvilla, S.; Mathew, M.K. Functional characterization of a transition metal ion transporter, OsZIP6 from rice (Oryza sativa L.). Plant Physiol. Bioch. 2015, 97, 165-174. [CrossRef]

25. Shimo, H.; Ishimaru, Y.; An, G.; Yamakawa, T.; Nakanishi, H.; Nishizawa, N.K. Low cadmium (LCD), a novel gene related to cadmium tolerance and accumulation in rice. J. Exp. Bot. 2011, 62, 5727-5734. [CrossRef]

26. Takahashi, R.; Ishimaru, Y.; Shimo, H.; Ogo, Y.; Senoura, T.; Nishizawa, N.K.; Nakanishi, H. The OsHMA2 transporter is involved in root-to-shoot translocation of Zn and Cd in rice. Plant Cell Environ. 2012, 35, 1948-1957. [CrossRef]

27. Satoh-Nagasawa, N.; Mori, M.; Nakazawa, N.; Kawamoto, T.; Nagato, Y.; Sakurai, K.; Takahashi, H.; Watanabe, A.; Akagi, H. Mutations in rice (Oryza sativa) Heavy Metal ATPase 2 (OsHMA2) restrict the translocation of zinc and cadmium. Plant Cell Physiol. 2012, 53, 213-224. [CrossRef]

28. Yamaji, N.; Xia, J.; Mitani-Ueno, N.; Yokosho, K.; Ma, J.F. Preferential delivery of zinc to developing tissues in rice is mediated by P-Type Heavy Metal ATPase OsHMA2. Plant Physiol. 2013, 162, 927-939. [CrossRef]

29. Luo, J.S.; Huang, J.; Zeng, D.L.; Peng, J.S.; Zhang, G.B.; Ma, H.L.; Guan, Y.; Yi, H.Y.; Fu, Y.L.; Han, B.; et al. A defensin-like protein drives cadmium efflux and allocation in rice. Nat. Commun. 2018, 9, 645. [CrossRef] [PubMed]

30. Yuan, L.; Yang, S.; Liu, B.; Zhang, M.; Wu, K. Molecular characterization of a rice metal tolerance protein, OsMTP1. Plant Cell Rep. 2012, 31, 67-79. [CrossRef] [PubMed]

31. Tan, L.; Zhu, Y.; Fan, T.; Peng, C.; Wang, J.; Sun, L.; Chen, C. OsZIP7 functions in xylem loading in roots and inter-vascular transfer in nodes to deliver $\mathrm{Zn} / \mathrm{Cd}$ to grain in rice. Biochem. Bioph. Res Co. 2019, 512, 112-118. [CrossRef] [PubMed]

32. Hao, X.; Zeng, M.; Wang, J.; Zeng, Z.; Dai, J.; Xie, Z.; Yang, Y.; Tian, L.; Chen, L.; Li, D. A node-expressed transporter OsCCX2 is involved in grain cadmium accumulation of rice. Front. Plant Sci. 2018, 9, 476. [CrossRef] [PubMed]

33. Uraguchi, S.; Kamiya, T.; Sakamoto, T.; Kasai, K.; Sato, Y.; Nagamura, Y.; Yoshida, A.; Kyozuka, J.; Ishikawa, S.; Fujiwara, T. Lowaffinity cation transporter (OsLCT1) regulates cadmium transport into rice grains. Proc. Natl. Acad. Sci. USA 2011, 108, 20959-20964. [CrossRef]

34. Liu, J.G.; Qu, P.; Zhang, W.; Dong, Y.; Li, L.; Wang, M. Variations among rice cultivars in subcellular distribution of Cd: The relationship between translocation and grain accumulation. Environ. Exp. Bot. 2014, 107, 25-31. [CrossRef] 
35. Miyadate, H.; Adachi, S.; Hiraizumi, A.; Tezuka, K.; Nakazawa, N.; Kawamoto, T.; Katou, K.; Kodama, I.; Sakurai, K.; Takahashi, H.; et al. OsHMA3, a P1B-type of ATPase affects root-to-shoot cadmium translocation in rice by mediating efflux into vacuoles. New Phytol. 2011, 189, 190-199. [CrossRef] [PubMed]

36. Ueno, D.; Yamaji, N.; Kono, I.; Huang, C.F.; Ando, T.; Yano, M.; Ma, J.F. Gene limiting cadmium accumulation in rice. Proc. Natl. Acad. Sci. USA 2010, 107, 16500-16505. [CrossRef]

37. Yan, J.; Wang, P.; Wang, P.; Yang, M.; Lian, X.; Tang, Z.; Huang, C.F.; Salt, D.E.; Zhao, F.J. A loss-of-function allele of OsHMA3 associated with high cadmium accumulation in shoots and grain of Japonica rice cultivars. Plant Cell Environ. 2016, 39, 1941-1954 [CrossRef] [PubMed]

38. Oda, K.; Otani, M.; Uraguchi, S.; Akihiro, T.; Fujiwara, T. Rice ABCG43 is Cd inducible and confers Cd tolerance on yeast. Biosci. Biotech. Bioch. 2011, 75, 1211-1213. [CrossRef]

39. Shim, D.; Hwang, J.U.; Lee, J.; Lee, S.; Choi, Y.; An, G.; Martinoia, E.; Lee, Y. Orthologs of the Class A4 Heat Shock Transcription Factor HsfA4a confer cadmium tolerance in wheat and rice. Plant Cell 2009, 21, 4031-4043. [CrossRef]

40. Harada, E.; Choi, Y.E.; Tsuchisaka, A.; Obata, H.; Sano, H. Transgenic tobacco plants expressing a rice cysteine synthase gene are tolerant to toxic levels of cadmium. J. Plant Physiol. 2001, 158, 655-661. [CrossRef]

41. Park, H.C.; Hwang, J.E.; Jiang, Y.; Kim, Y.J.; Kim, S.H.; Nguyen, X.C.; Kim, C.Y.; Chung, W.S. Functional characterisation of two phytochelatin synthases in rice (Oryza sativa cv. Milyang 117) that respond to cadmium stress. Plant Biol. 2019, 21, 854-861. [CrossRef]

42. Jin, S.; Cheng, Y.; Guan, Q.; Liu, D.; Takano, T.; Liu, S. A metallothionein-like protein of rice (rgMT) functions in E. coli and its gene expression is induced by abiotic stresses. Biotechnol. Lett. 2006, 28, 1749-1753. [CrossRef]

43. Yang, J.; Gao, M.X.; Hu, H.; Ding, X.M.; Lin, H.W.; Wang, L.; Xu, J.M.; Mao, C.Z.; Zhao, F.J.; Wu, Z.C. OsCLT1, a CRT-like transporter 1, is required for glutathione homeostasis and arsenic tolerance in rice. New Phytol. 2016, 211, 658-670. [CrossRef]

44. Agrawal, G.K.; Agrawal, S.K.; Shibato, J.; Iwahashi, H.; Rakwal, R. Novel rice MAP kinases OsMSRMK3 and OsWJUMK1 involved in encountering diverse environmental stresses and developmental regulation. Biochem. Biophys. Res. Commun. 2003, 300, 775-783. [CrossRef]

45. Yu, C.; Sun, C.; Shen, C.; Wang, S.; Liu, F.; Liu, Y.; Chen, Y.; Li, C.; Qian, Q.; Aryal, B.; et al. The auxin transporter, OsAUX1, is involved in primary root and root hair elongation and in Cd stress responses in rice (Oryza sativa L.). Plant J. 2015, 83, 818-830. [CrossRef]

46. Lee, S.; Kim, Y.Y.; Lee, Y.; An, G. Rice P ${ }_{1 \mathrm{~B}}$-Type Heavy-Metal ATPase, OsHMA9, is a metal efflux protein. Plant Physiol. 2007, 145, 831-842. [CrossRef]

47. Liu, X.S.; Feng, S.J.; Zhang, B.Q.; Wang, M.Q.; Cao, H.W.; Rono, J.K.; Chen, X.; Yang, Z.M. OsZIP1 functions as a metal efflux transporter limiting excess zinc, copper and cadmium accumulation in rice. BMC Plant Biol. 2019, 19, 283. [CrossRef]

48. Fu, S.; Lu, Y.S.; Zhang, X.; Yang, G.; Chao, D.; Wang, Z.; Shi, M.; Chen, J.; Chao, D.Y.; Li, R.; et al. The ABC transporter OsABCG36 is required for Cd tolerance in rice. J. Exp. Bot. 2019, 70, 5909-5918. [CrossRef]

49. Zhou, Q.; Wang, H.; Zhang, Y.; Dong, Q.; Meng, S.; Cao, L.; Shao, G.; Shen, X. Changes in cadmium concentration in rice plants under different cadmium levels and expression analysis of genes retated to cadmium regulation. Chin. J. Rice Sci. 2016, 30, 380-388. [CrossRef]

50. Wang, M.; Wang, L.; Zhao, S.; Li, S.; Lei, X.; Qin, L.; Sun, X.; Chen, S. Manganese facilitates cadmium stabilization through physicochemical dynamics and amino acid accumulation in rice rhizosphere under flood-associated low pe+pH. J. Hazard. Mater. 2021, 416, 126079. [CrossRef]

51. Li, Z.; Yang, W.; Zou, J.; Zhou, H.; Zeng, Q.; Liao, B. Effects of calcium magnesium phosphate fertilizer on Cd bioavailability in soil and Cd contents in rice. Acta Sci. Circumst. 2017, 37, 2322-2330. [CrossRef]

52. Chaney, R.L. How does contamination of rice soils with $\mathrm{Cd}$ and $\mathrm{Zn}$ cause high incidence of human Cd disease in subsistence rice farmers. Curr. Pollut. Rep. 2015, 1, 13-22. [CrossRef]

53. Guo, J.H.; Liu, X.J.; Zhang, Y.; Shen, J.L.; Han, W.X.; Zhang, W.F.; Christie, P.; Goulding, K.W.T.; Vitousek, P.M.; Zhang, F.S Significant acidification in major Chinese croplands. Science 2010, 327, 1008-1010. [CrossRef]

54. Chen, W.; Peng, L.; Hu, K.; Zhang, Z.; Peng, C.; Teng, C.; Zhou, K. Spectroscopic response of soil organic matter in mining area to $\mathrm{Pb} / \mathrm{Cd}$ heavy metal interaction: A mirror of coherent structural variation. J. Hazard. Mater. 2020, 393, 122425. [CrossRef]

55. Sheng, X.; He, L.; Wang, Q.; Ye, H.; Jiang, C.Y. Effects of inoculation of biosurfactant-producing Bacillus sp. J119 on plant growth and cadmium uptake in a cadmium-amended soil. J. Hazard. Mater. 2008, 155, 17-22. [CrossRef]

56. Chai, M.W.; Shi, F.C.; Li, R.L.; Liu, F.C.; Qiu, G.Y.; Liu, L.M. Effect of $\mathrm{NaCl}$ on growth and Cd accumulation of halophyte Spartina alterniflora under $\mathrm{CdCl}_{2}$ stress. S. Afr. J. Bot. 2013, 85, 63-69. [CrossRef]

57. Manousaki, E.; Kadukova, J.; Papadantonakis, N.; Kalogerakis, N. Phytoextraction and phytoexcretion of Cd by the leaves of Tamarix smyrnensis growing on contaminated non-saline and saline soils. Environ. Res. 2008, 106, 326-332. [CrossRef]

58. Shao, J.F.; Che, J.; Yamaji, N.; Shen, R.F.; Ma, J.F. Silicon reduces cadmium accumulation by suppressing expression of transporter genes involved in cadmium uptake and translocation in rice. J. Exp. Bot. 2017, 68, 5641-5651. [CrossRef]

59. Zhu, H.; Chen, C.; Xu, C.; Zhu, Q.; Huang, D. Effects of soil acidification and liming on the phytoavailability of cadmium in paddy soils of central subtropical China. Environ. Pollut. 2016, 219, 99-106. [CrossRef]

60. Jalloh, M.A.; Chen, J.; Zhen, F.; Zhang, G. Effect of different $\mathrm{N}$ fertilizer forms on antioxidant capacity and grain yield of rice growing under Cd stress. J. Hazard. Mater. 2009, 162, 1081-1085. [CrossRef] 
61. Wei, S.; Li, Y.; Zhou, Q.; Srivastava, M.; Chiu, S.; Zhan, J.; Wu, Z.; Sun, T. Effect of fertilizer amendments on phytoremediation of Cd-contaminated soil by a newly discovered hyperaccumulator Solanum nigrum L. J. Hazard. Mater. 2010, 176, 269-273. [CrossRef] [PubMed]

62. Houben, D.; Evrard, L.; Sonnet, P. Mobility, bioavailability and pH-dependent leaching of cadmium, zinc and lead in a contaminated soil amended with biochar. Chemosphere 2013, 92, 1450-1457. [CrossRef] [PubMed]

63. Ondrasek, G.; Romic, D.; Rengel, Z. Interactions of humates and chlorides with cadmium drive soil cadmium chemistry and uptake by radish cultivars. Sci. Total Environ. 2020, 702, 134887. [CrossRef] [PubMed]

64. Nosek, M.; Kaczmarczyk, A.; Śliwa, M.; Jedrzejczyk, R.; Kornas, A.; Supel, P.; Kaszycki, P.; Miszalski, Z. The response of a model $\mathrm{C}_{3}$ /CAM intermediate semi-halophyte Mesembryanthemum crystallinum L. to elevated cadmium concentrations. J. Plant Physiol. 2019, 240, 153005. [CrossRef]

65. Fujimaki, S.; Suzui, N.; Ishioka, N.S.; Kawachi, N.; Ito, S.; Chino, M.; Nakamura, S. Tracing cadmium from culture to spikelet: Noninvasive imaging and quantitative characterization of absorption, transport, and accumulation of cadmium in an intact rice plant. Plant Physiol. 2010, 152, 1796-1806. [CrossRef]

66. Rodda, M.S.; Li, G.; Reid, R.J. The timing of grain Cd accumulation in rice plants: The relative importance of remobilisation within the plant and root Cd uptake post-flowering. Plant Soil 2011, 347, 105-114. [CrossRef]

67. Tanaka, K.; Fujimaki, S.; Fujiwara, T.; Yoneyama, T.; Hayashi, H. Quantitative estimation of the contribution of the phloem in cadmium transport to grains in rice plants (Oryza sativa L.). Front. Plant Sci. 2007, 53, 72-77. [CrossRef]

68. Zhou, Q.; Shao, G.S.; Zhang, Y.X.; Dong, Q.; Wang, H.; Cheng, S.H.; Cao, L.Y.; Shen, X.H. The difference of cadmium accumulation between the indica and japonica subspecies and the mechanism of it. Plant Growth Regul. 2017, 81, 523-532. [CrossRef]

69. Lin, Y.F.; Aarts, M.G.M. The molecular mechanism of zinc and cadmium stress response in plants. Cell. Mol. Life Sci. 2012, 69, 3187-3206. [CrossRef]

70. Weber, M.; Trampczynska, A.; Clemens, S. Comparative transcriptome analysis of toxic metal responses in Arabidopsis thaliana and the $\mathrm{Cd}^{2+}$ hypertolerant facultative metallophyte Arabidopsis halleri. Plant Cell Environ. 2010, 29, 950-963. [CrossRef]

71. Hall, J.L. Cellular mechanisms for heavy metal detoxification and tolerance. J. Exp. Bot. 2002, 53, 1-11. [CrossRef]

72. Yu, H.; Guo, J.; Li, Q.; Zhang, X.; Huang, H.; Huang, F.; Yang, A.; Li, T. Characteristics of cadmium immobilization in the cell wall of root in a cadmium-safe rice line (Oryza sativa L.). Chemosphere 2020, 241, 125095. [CrossRef]

73. Ondrasek, G.; Rengel, Z.; Clode, P.L.; Kilburn, M.R.; Guagliardo, P.; Romic, D. Zinc and cadmium mapping by NanoSIMS within the root apex after short-term exposure to metal contamination. Ecotox. Environ. Safe. 2019, 171, 571-578. [CrossRef]

74. Kuramata, M.; Masuya, S.; Takahashi, Y.; Kitagawa, E.; Inoue, C.; Ishikawa, S.; Youssefian, S.; Kusano, T. Novel Cysteine-Rich Peptides from Digitaria ciliaris and Oryza sativa enhance tolerance to cadmium by limiting its cellular accumulation. Plant Cell Physiol. 2009, 50, 106-117. [CrossRef]

75. Yu, H.; Wu, Y.; Huang, H.; Zhan, J.; Wang, K.; Li, T. The predominant role of pectin in binding Cd in the root cell wall of a high Cd accumulating rice line (Oryza sativa L.). Ecotox. Environ. Safe. 2020, 206, 111210. [CrossRef]

76. Zhu, C.Q.; Cao, X.C.; Zhu, L.F.; Hu, W.J.; Hu, A.Y.; Bai, Z.G.; Zhong, C.; Sun, L.M.; Liang, Q.D.; Huang, J.; et al. Ammonium mitigates Cd toxicity in rice (Oryza sativa) via putrescine-dependent alterations of cell wall composition. Plant Physiol. Bioch. 2018, 132, 189-201. [CrossRef]

77. Han, Y.; Sa, G.; Sun, J.; Shen, Z.; Zhao, R.; Ding, M.; Deng, S.; Lu, Y.; Zhang, Y.; Shen, X.; et al. Overexpression of Populus euphratica xyloglucan endotransglucosylase/hydrolase gene confers enhanced cadmium tolerance by the restriction of root cadmium uptake in transgenic tobacco. Environ. Exp. Bot. 2014, 100, 74-83. [CrossRef]

78. Liu, C.L.; Gao, Z.Y.; Shang, L.G.; Yang, C.H.; Ruan, B.P.; Zeng, D.L.; Guo, L.B.; Zhao, F.J.; Huang, C.F.; Qian, Q. Natural variation in the promoter of OsHMA3 contributes to differential grain cadmium accumulation between Indica and Japonica rice. J. Integr. Plant Biol. 2020, 62, 60-75. [CrossRef]

79. Morel, M.; Crouzet, J.; Gravot, A.; Auroy, P.; Leonhardt, N.; Vavasseur, A.; Richaud, P. AtHMA3, a P1B-ATPase allowing $\mathrm{Cd} / \mathrm{Zn} / \mathrm{Co} / \mathrm{Pb}$ vacuolar storage in Arabidopsis. Plant Physiol. 2009, 149, 894-904. [CrossRef]

80. Liu, H.; Zhao, H.; Wu, L.; Liu, A.; Zhao, F.J.; Xu, W. Heavy metal ATPase 3 (HMA3) confers cadmium hypertolerance on the cadmium/zinc hyperaccumulator Sedum plumbizincicola. New Phytol. 2017, 215, 687-698. [CrossRef]

81. Prévéral, S.; Gayet, L.; Moldes, C.; Hoffmann, J.; Mounicou, S.; Gruet, A.; Reynaud, F.; Lobinski, R.; Verbavatz, J.M.; Vavasseur, A.; et al A common highly conserved cadmium detoxification mechanism from bacteria to humans: Heavy metal tolerance conferred by the ATP-binding cassette $(\mathrm{ABC})$ transporter SpHMT1 requires glutathione but not metal-chelating phytochelatin peptides. J. Biol. Chem. 2009, 284, 4936-4943. [CrossRef]

82. Park, J.; Song, W.Y.; Ko, D.; Eom, Y.; Hansen, T.H.; Schiller, M.; Lee, T.G.; Martinoia, E.; Lee, Y. The phytochelatin transporters AtABCC1 and AtABCC2 mediate tolerance to cadmium and mercury. Plant J. 2012, 69, 278-288. [CrossRef]

83. Brunetti, P.; Zanella, L.; De Paolis, A.; Di Litta, D.; Cecchetti, V.; Falasca, G.; Barbieri, M.; Altamura, M.M.; Costantino, P.; Cardarelli, M. Cadmium-inducible expression of the ABC-type transporter AtABCC3 increases phytochelatin-mediated cadmium tolerance in Arabidopsis. J. Exp. Bot. 2015, 66, 3815-3829. [CrossRef]

84. Grill, E.; Löffler, S.; Winnacker, E.L.; Zenk, M.H. Phytochelatins, the heavy-metal-binding peptides of plants, are synthesized from glutathione by a specific $\gamma$-glutamylcysteine dipeptidyl transpeptidase (phytochelatin synthase). Proc. Natl. Acad. Sci. USA 1989, 86, 6838-6842. [CrossRef] 
85. Li, Z.S.; Lu, Y.P.; Zhen, R.G.; Szczypka, M.; Thiele, D.J.; Rea, P.A. A new pathway for vacuolar cadmium sequestration in Saccharomyces cerevisiae: YCF1-catalyzed transport of bis(glutathionato) cadmium. Proc. Natl. Acad. Sci. USA 1997, 94, 42-47. [CrossRef]

86. Wang, S.; Dong, Q.; Wang, Z. Differential effects of citric acid on cadmium uptake and accumulation between tall fescue and Kentucky bluegrass. Ecotox. Environ. Safe. 2017, 145, 200-206. [CrossRef]

87. Howden, R.; Goldsbrough, P.B.; Andersen, C.R.; Cobbett, C.S. Cadmium-sensitive, cad1 mutants of Arabidopsis thaliana are phytochelatin deficient. Plant Physiol. 1995, 107, 1059-1066. [CrossRef] [PubMed]

88. Haag-Kerwer, A.; Schäfer, H.J.; Heiss, S.; Walter, C.; Rausch, T. Cadmium exposure in Brassica juncea causes a decline in transpiration rate and leaf expansion without effect on photosynthesis. J. Exp. Bot. 1999, 50, 1827-1835. [CrossRef]

89. Venkataramaiah, N.; Ramakrishna, S.V.; Sreevathsa, R. Overexpression of phytochelatin synthase (AtPCS) in rice for tolerance to cadmium stress. Biologia 2011, 66, 1060-1073. [CrossRef]

90. Gisbert, C.; Ros, R.; Haro, A.D.; Walker, D.J.; Bernal, M.P.; Serrano, R.; Navarro-Aviñó, J. A plant genetically modified that accumulates $\mathrm{Pb}$ is especially promising for phytoremediation. Biochem. Biophys. Res. Commun. 2003, 303, 440-445. [CrossRef]

91. Gasic, K.; Korban, S.S. Transgenic Indian mustard (Brassica juncea) plants expressing an Arabidopsis phytochelatin synthase (AtPCS1) exhibit enhanced As and Cd tolerance. Plant Mol. Biol. 2007, 64, 361-369. [CrossRef]

92. Wojas, S.; Clemens, S.; Hennig, J.; Skodowska, A.; Kopera, E.; Schat, H.; Bal, W.; Antosiewicz, D.M. Overexpression of phytochelatin synthase in tobacco: Distinctive effects of AtPCS1 and CePCS genes on plant response to cadmium. J. Exp. Bot. 2008, 59, 2205-2219. [CrossRef]

93. Wang, F.; Wang, Z.; Zhu, C. Heteroexpression of the wheat phytochelatin synthase gene (TaPCS1) in rice enhances cadmium sensitivity. Acta Bioch. Bioph. Sin. 2012, 44, 886-893. [CrossRef]

94. Pomponi, M.; Censi, V.; Di Girolamo, V.; De Paolis, A.; di Toppi, L.S.; Aromolo, R.; Costantino, P.; Cardarelli, M. Overexpression of Arabidopsis phytochelatin synthase in tobacco plants enhances $\mathrm{Cd}^{2+}$ tolerance and accumulation but not translocation to the shoot. Planta 2006, 223, 180-190. [CrossRef]

95. Li, H.; Liu, Y.; Zeng, G.; Zhou, L.; Wang, X.; Wang, Y.; Wang, C.; Hu, X.; Xu, W. Enhanced efficiency of cadmium removal by Boehmeria nivea (L.) Gaud. in the presence of exogenous citric and oxalic acids. J. Environ. Sci. 2014, 26, 2508-2516. [CrossRef]

96. Ehsan, S.; Ali, S.; Noureen, S.; Mahmood, K.; Farid, M.; Ishaque, W.; Shakoor, M.B.; Rizwan, M. Citric acid assisted phytoremediation of copper by Brassica napus L. Ecotox. Environ. Safe. 2015, 120, 310-317. [CrossRef]

97. Ondrasek, G.; Clode, P.L.; Kilburn, M.R.; Guagliardo, P.; Romić, D.; Rengel, Z. Zinc and cadmium mapping in the apical shoot and hypocotyl tissues of radish by high-resolution Secondary Ion Mass Spectrometry (NanoSIMS) after short-term exposure to metal contamination. Int. J. Environ. Res. Public Health 2019, 16, 373. [CrossRef]

98. Ondrasek, G.; Rengel, Z.; Romic, D. Humic acids decrease uptake and distribution of trace metals, but not the growth of radish exposed to cadmium toxicity. Ecotox. Environ. Safe. 2018, 151, 55-61. [CrossRef]

99. Panda, P.; Nath, S.; Chanu, T.T.; Sharma, G.D.; Panda, S.K. Cadmium stress-induced oxidative stress and role of nitric oxide in rice (Oryza sativa L.). Acta Physiol. Plant. 2011, 33, 1737-1747. [CrossRef]

100. Zhu, Y.L.; Pilon-Smits, E.A.H.; Jouanin, L.; Terry, N. Overexpression of Glutathione Synthetase in Indian mustard enhances cadmium accumulation and tolerance. Plant Physiol. 1999, 119, 73-80. [CrossRef]

101. Zhu, Y.L.; Pilon-Smits, E.A.H.; Tarun, A.S.; Weber, S.U.; Jouanin, L.; Terry, N. Cadmium tolerance and accumulation in Indian mustard is enhanced by overexpressing $\gamma$-Glutamylcysteine Synthetase. Plant Physiol. 1999, 121, 1169-1177. [CrossRef]

102. Li, Y.; Dhankher, O.P.; Carreira, L.; Balish, R.S.; Meagher, R.B. Arsenic and mercury tolerance and cadmium sensitivity in Arabidopsis plants expressing bacterial $\gamma$-glutamylcysteine synthetase. Environ. Toxicol. Chem. 2005, 24, 1376-1386. [CrossRef]

103. Zhang, C.; Yin, X.; Gao, K.; Ge, Y.; Cheng, W. Non-protein thiols and glutathione S-transferase alleviate Cd stress and reduce root-to-shoot translocation of Cd in rice. J. Plant Nutr. Soil Sci. 2013, 176, 626-633. [CrossRef]

104. Vivancos, P.D.; Dong, Y.; Ziegler, K.; Markovic, J.; Pallardo, F.V.; Pellny, T.K.; Verrier, P.J.; Foyer, C. Recruitment of glutathione into the nucleus during cell proliferation adjusts whole-cell redox homeostasis in Arabidopsis thaliana and lowers the oxidative defence shield. Plant J. 2010, 64, 825-838. [CrossRef]

105. Giblin, F.J. Glutathione: A vital lens antioxidant. J. Ocul. Pharmacol. Ther. 2000, 16, 121-135. [CrossRef]

106. Zhang, B.L.; Shang, S.H.; Zhang, H.T.; Jabeen, Z.; Zhang, G.P. Sodium chloride enhances cadmium tolerance through reducing cadmium accumulation and increasing anti-oxidative enzyme activity in tobacco. Environ. Toxicol. Chem. 2013, 32, 1420-1425. [CrossRef]

107. Dhakarey, R.; Raorane, M.L.; Treumann, A.; Peethambaran, P.K.; Schendel, R.R.; Sahi, V.P.; Hause, B.; Bunzel, M.; Henry, A.; Kohli, A.; et al. Physiological and proteomic analysis of the rice mutant cpm2 suggests a negative regulatory role of Jasmonic acid in drought tolerance. Front. Plant Sci. 2017, 8, 1903. [CrossRef]

108. Singh, I.; Shah, K. Exogenous application of methyl jasmonate lowers the effect of cadmium-induced oxidative injury in rice seedlings. Phytochemistry 2014, 108, 57-66. [CrossRef]

109. Ondrasek, G.; Begic, H.B.; Zovko, M.; Filipović, L.; Meriño-Gergichevich, C.; Savić, R.; Rengel, Z. Biogeochemistry of soil organic matter in agroecosystems \& environmental implications. Sci. Total Environ. 2019, 658, 1559-1573. [CrossRef] 